
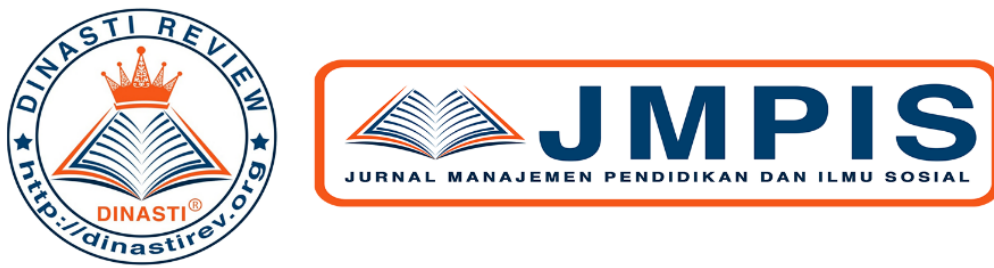

+6281387654578 (9)

+6281387654578 (Q)

https://dinastirev.org/JMPIS (2)

dinasti-info@gmail.com G.

\title{
BUDAYA ORGANISASI DAN MOTIVASI KERJA PADA PT. X (PERUSAHAAN PMA
}

\section{BATAM)}

Faradillah Dwi Arhany ${ }^{1)}$

${ }^{1)}$ Universitas Terbuka, Indonesia

ARTICLE INFORMATION

Received: 27 April 2020

Revised: 13 Mei 2020

Issued: 17 Mei 2020

Corresponding author: first author

E-mail:

faradillah.chemistry09@gmail.com

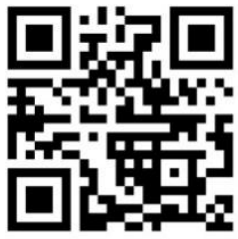

DOI:10.38035/JMPIS

\begin{abstract}
Abstrak: Perusahaan merupakan salah satu jenis organ dimana salah satu jenis perusahaan yang ada di Indo adalah Perusahaan Modal Asing. Setiap perusahaan men budaya organisasi tersendiri yang membedakannya de perusahaan lain sebagai suatu organisasi, begitu pula de PT. X sebagai perusahaan PMA yang ada di Batam. Bu organisasi di PT. X beberapa kali mengalami perub karena terjadi pergantian direktur utama serta banya karyawan yang resign dari perusahaan sehingga terbe budaya organisasi baru. Perubahan yang terjadi juga memengaruhi motivasi karyawan baik yang memilih re ataupun tetap bertahan di PT. X. Penelitian dilak menggunakan metode penelitian deskriptif karena menggambarkan objek penelitian berdasarkan fakta tampak dimana dari hasil diperoleh bahwa budaya organ di PT. X mengalami perubahan karena banyaknya kary: yang resign, selain itu pergantian kepemimpinan juga memengaruhi perubahan budaya organisasi serta mot yang terjadi di PT. X. Karyawan yang masih bert disebabkan oleh existence needs dan relatedness $n$ karyawan tersebut.
\end{abstract}

Kata Kunci: Perusahaan PMA, budaya organisasi, motivasi kerja

\section{PENDAHULUAN}

Organisasi merupakan suatu wadah dimana sekelompok orang menjadi anggotanya untuk menggerakkan organisasi tersebut demi mencapai tujuan bersama, tujuan ini telah disepakati bersama oleh para pendiri dan anggota organisasi terdahulu yang dijadikan visi dan misi organisasi. Sebagai sebuah wadah, tentunya sekelompok orang yang menjadi bagian dari organisasi tersebut terdiri dari orang-orang yang memiliki latar belakang yang berbeda. Namun 
perbedaan ini bisa menjadi kelebihan dari organisasi itu sendiri dimana akan semakin banyak ide dan terciptanya kreativitas yang berbeda diantara para anggota yang menjadi ciri khas organisasi serta demi kemajuan organisasi ke depannya.

Perusahaan yang merupakan salah satu organisasi yang didirikan untuk memproduksi berbagai barang dan jasa menjadi suatu lembaga yang hasil produksinya baik itu berupa barang maupun jasa dijual ke masyarakat agar memeroleh laba atau keuntungan. Salah satu jenis perusahaan yang ada di Indonesia adalah perusahaan PMA (penanaman modal asing), perusahaan PMA dibangun dengan menanam modal agar dapat melakukan usaha di wilayah Indonesia oleh penanam modal asing. Salah satu daerah di Indonesia yang menjadi daerah industri adalah Batam, tak ayal ada banyak perusahaan PMA yang berdiri di daerah Batam.

Pada setiap perusahaan yang merupakan salah satu bentuk dari suatu organisasi, ada ciri khas yang membedakan antara organisasi satu dan lainnya. Ciri khas ini berupa budaya organisasi dimana menurut Robbins dan Judge (2008, h. 256) budaya organisasi menjadi satu sistem yang dianut oleh anggota-anggota dalam organisasi dan menjadi karakteristik pembeda organisasi satu dengan yang lain seperti pemimpin, bawahan serta komponen lain dalam organisasi. Hal ini juga terbentuk dari interaksi dan kebiasaan seluruh komponen organisasi, terutama pimpinan dengan bawahan. Seorang karyawan yang akan bergabung dengan suatu perusahaan harus menerima dan mulai bersinergi dengan budaya organisasi perusahaan tempatnya bekerja sekali pun karyawan tersebut memiliki karakter diri dan budaya atau kebiasaan yang berbeda. Hal inilah yang kadang menjadi alasan seorang karyawan untuk bertahan atau merasa tidak betah dengan perusahaan dimana dia bekerja.

Selain budaya organisasi, motivasi sering kali menjadi faktor yang memengaruhi kinerja karyawan serta alasan seorang karyawan merasa betah dengan pekerjaannya. Motivasi merupakan dorongan yang berasal dari dalam diri seseorang yang muncul karena seseorang merasa kebutuhan fisiologis dan psikologisnya tidak terpenuhi. Dorongan ini yang akan menjadi pemicu seseorang untuk senantiasa berusaha agar tujuannya dapat terpenuhi. Motivasi dalam bekerja dapat berasal dari faktor internal maupun eksternal. Apapun alasan yang melatar belakangi, seseorang yang memiliki motivasi akan selalu berusaha dan melakukan hal yang jauh lebih baik daripada seseorang yang tidak memiliki motivasi karena seyogianya orang yang memiliki tujuan untuk dicapai akan berusaha maksimal untuk dapat mencapai tujuan tersebut.

PT. X merupakan salah satu perusahaan PMA yang ada di Batam, dimana seluruh saham atau kepemilikannya berasal dari modal asing. Sebagai perusahaan PMA, PT. X mempekerjakan orang asing sebagai manajemen inti yang memback-up pekerjaan utama yang dilakukan di Singapur sedangkan seluruh karyawan lain seperti manajer laboratorium dan karyawan merupakan orang Indonesia yang direkrut baik secara lokal (daerah Batam) maupun direkrut dari luar wilayah Batam.

PT. X menawarkan jasa berupa laboratorium analisis, namun jasa ini hanya diperuntukkan bagi satu customer saja yang merupakan perusahaan berbeda namun satu manajemen inti dengan PT. X. Selain melakukan analisis terhadap produk yang dihasilkan customer-nya, PT.X juga melakukan research dan develop product yang nantinya bisa 
diproduksi oleh perusahaan customer. Pada dasarnya PT. X bertindak sebagai bagian support agar perusahaan yang bertindak sebagai customer dapat menjual produknya, baik di dalam maupun di luar negeri.

Sebagai sebuah perusahaan, PT. X tentu memiliki budaya organisasi sendiri yang dilakukan dan senantiasa diajarkan kepada karyawan yang baru bergabung dengan PT. X. Budaya organisasi di PT. X beberapa kali mengalami perubahan yang disesuaikan dengan kondisi kerja saat itu, perubahan itu terjadi saat karyawan lama yang menjadi bagian dari orangorang yang turut memulai dan membangun budaya organisasi resign dari perusahaan serta saat direktur utama PT. X meninggal dunia dan posisinya digantikan oleh wakil direktur. Namun, sekalipun budaya organisasi mengalami perubahan akan tetapi asumsi dasar dan landasan filosofis organisasi tetap dipertahankan dan tidak berdampak terhadap perubahan yang terjadi.

Terjadinya perubahan budaya organisasi dan pergantian kepemimpinan membuat beberapa karyawan tidak dapat bertahan di PT. X sehingga memilih keluar, perubahan yang ada juga turut memengaruhi motivasi karyawan sehingga penurunan kinerja terjadi atau cenderung stagnan. Karyawan yang merasa tidak memiliki motivasi lagi untuk bekerja di PT. X karena merasa kondisi lingkungan kerja dan budaya organisasi tidak sejalan lagi kemudian memilih untuk mencari pekerjaan di tempat lainnya. Maka, melalui penelitian ini akan dipaparkan mengenai budaya organisasi dan motivasi kerja di PT. X.

\section{KAJIAN PUSTAKA}

\section{Perusahaan PMA}

Perusahaan PMA atau penanaman modal asing adalah perusahaan dimana investasi dilakukan oleh orang atau sekelompok orang asing untuk dapat melakukan usaha di wilayah Indonesia dengan membangun, membeli atau mengakuisisi perusahaan yang ada di Indonesia. Selain itu untuk menarik investor untuk melakukan investasi di wilayah Indonesia, pemerintah Indonesia menerapkan aturan yang tertuang dalam undang-undang ataupun peraturan lainnya yang memberikan kemudahan bagi investor untuk dapat melakukan investasi dengan mudah.

Berdasarkan Undang-Undang Republik Indonesia Nomor 25 Rahun 2007 tentang Penanaman Modal, pada pasal 1 ayat 3 dijelaskan bahwa penanaman modal asing adalah kegiatan menanam modal untuk melakukan usaha di wilayah negara Republik Indonesia yang dilakukan oleh penanam modal asing, baik yang menggunakan modal asing sepenuhnya maupun yang berpatungan dengan penanam modal dalam negeri (Indonesia. Otoritas Jasa Keuangan (OJK), 2016).

Penanaman modal asing ini diwajibkan dalam bentuk perseroan terbatas. Penanaman Modal Asing (PMA) lebih banyak mempunyai kelebihan diantaranya sifatnya jangka panjang, banyak memberikan adil (andil) dalam alih teknologi, alih keterampilan manajemen, membuka lapangan kerja baru. Lapangan kerja ini, sangat penting bagi negara sedang berkembang mengingat terbatasnya kemampuan pemerintah untuk penyediaan lapangan kerja (Wikipedia, 2017). 


\section{Budaya Organisasi}

Menurut Mangkunegara (2005) dalam Kusumawardani (2010, h. 159), budaya organisasi adalah seperangkat asumsi atau sistem keyakinan, nilai-nilai dan norma yang dikembangkan dalam organisasi yang dijadikan pedoman tingkah laku bagi anggotaanggotanya untuk mengatasi masalah adaptasi eksternal dan integrasi internal. Druicker dan Owens dalam Kusumawardani (2010, h. 159-160) juga mendefinisikan bahwa budaya organisasi adalah pokok penyelesaian masalah-masalah eksternal dan internal yang pelaksanaannya dilakukan secara konsisten oleh suatu kelompok yang kemudian mewariskan kepada anggota-anggota baru sebagai cara yang tepat untuk memahami, memikirkan dan merasakan terhadap masalah-masalah.

Budaya organisasi akan segera terbentuk segera setelah organisasi tersebut didirikan. Hal ini misalnya ditegaskan oleh Schein yang mengatakan bahwa pembentukan budaya organisasi tidak bisa dipisahkan dari peran para pendiri organisasi. Prosesnya mengikuti alur sebagai berikut (Sobirin, 2018, h. 8.60) :

a. Para pendiri dan pimpinan lainnya membawa serta satu set asumsi dasar, nilai-nilai, perspektif dan artefak ke dalam organisasi dan menanamkannya kepada para karyawan.

b. Budaya muncul ketika para anggota organisasi berinteraksi satu sama lain untuk memecahkan masalah-masalah pokok organisasi, yakni masalah integrasi internal dan adaptasi eksternal.

c. Secara perorangan, masing-masing organisasi boleh menjadi seorang pencipta budaya baru (culture creator) dengan mengembangkan berbagai cara untuk menyelesaikan persoalan-persoalan individual, seperti persoalan identitas diri, kontrol dan pemenuhan kebutuhan serta bagaimana agar bisa diterima oleh lingkungan organisasi yang diajarkan kepada generasi penerus.

Budaya organisasi yang kuat dan sehat dapat difungsikan sebagai tuntutan yang mengikat para karyawan karena diformulasikan secara formal ke dalam berbagai peraturan dan ketentuan perusahaan. Dengan demikian, budaya organisasi akan menciptakan peningkatan produktivitas, dan kinerja. Budaya organisasi yang kuat dapat mempengaruhi efektivitas organisasi, karena untuk mencapai efektivitas maka dibutuhkan budaya organisasi, strategi, lingkungan, dan teknologi yang sesuai. Budaya organisasi lebih kuat apabila terdapat kecocokan budaya (culture fit) dengan variabel-variabel penting lainnya.

Secara umum dapat disimpulkan bahwa elemen budaya organisasi terdiri atas dua elemen pokok, yaitu elemen yang bersifat idealistis dan elemen yang bersifat behavioural (Sobirin, 2018, h. 8.45)

a. Elemen yang Idealistik

Dikatakan idealistik karena elemen ini menjadi ideologi organisasi yang tidak mudah berubah walaupun disisi lain organisasi secara natural harus selalu berubah dan beradaptasi dengan lingkungannya. Elemen ini bersifat terselubung (elusive), tidak tampak ke permukaan (hidden), dan hanya orang-orang tertentu (biasanya elite 
organisasi) yang tahu apa sesungguhnya ideologi mereka dan mengapa organisasi tersebut didirikan (Sobirin, 2018, h. 8.46).

Elemen idealistik melekat pada diri pemilik dalam bentuk doktrin, falsafah hidup, atau nilai-nilai individual para pendiri atau pemilik organisasi dalam menentukan arah tujuan dan menjalankan kehidupan sehari-hari organisasi (Sobirin, 2018, h. 8.46).

b. Elemen Behavioral

Elemen yang bersifat behavioural adalah elemen yang kasat mata, muncul ke permukaan dalam bentuk perilaku sehari-hari para anggotanya dan bentuk-bentuk lain seperti desain dan arsitektur organisasi, elemen ini mudah diamati, dipahami dan diinterpretasikan meskipun kadang tidak sama dengan interpretasi dengan orang yang terlibat langsung dalam organisasi. Cara paling mudah mengidentifikasi budaya organisasi adalah dengan mengamati bagaimana para anggota organisasi berperilaku dan kebiasaan yang mereka lakukan (Sobirin, 2018, h. 8.49).

c. Keterkaitan antara Elemen Idealistis dan Behavioral

Secara umum, bisa dikatakan bahwa kedua elemen budaya organisasi tersebut (elemen yang idealistis dan behavioral) bukan elemen yang terpisah satu sama lain. Namun, elemen kedua (yang bersifat behavioral), lebih rentan terhadap perubahan dibanding elemen pertama. Penyebabnya, elemen kedua bersinggungan langsung dengan lingkungan eksternal organisasi sehingga ketika budaya sebuah organisasi terpaksa harus berubah, misalnya karena desakan lingkungan, biasanya yang pertama kali berubah adalah elemen kedua, sedangkan elemen pertama jarang mengalami perubahan, di samping karena menjadi falsafah hidup organisasi, juga karena letaknya yang terselubung (Sobirin, 2018, h. 8.51).

Menurut Kusumawardani (2010, h. 161), penetapan ukuran budaya antara lain:

a. Inovasi merupakan tingkat daya pendorong karyawan untuk bersikap inovatif. Keinovatifan seseorang dapat diukur dari kreativitas dan kebebasan/independensinya.

b. Integrasi adalah sejauh mana suatu organisasi dapat mendorong unit-unit organisasi untuk bekerja dengan cara yang terkoordinasi. Integrasi dalam organisasi dapat diukur dengan kemampuan dalam berkoordinasi dan kebersamaan.

c. Perilaku kepemimpinan adalah perilaku atau cara yang dipergunakan oleh pemimpin dalam mempengaruhi pikiran, perasaan, sikap dan perilaku anggota organisasi. Perilaku pemimpin dapat diukur dengan kemampuan pimpinan dalam mengarahkan, mendukung, dan memberi penghargaan kepada bawahan.

d. Stabilitas merupakan tingkat penekanan aktivitas organisasi dalam mempertahankan status quo berbanding pertumbuhan. Aktivitas organisasi dapat dikatakan stabil jika mampu melaksankan tugas dengan efisien dan efektif serta adanya perasaan bangga dan ikut memiliki organisasi

e. Orientasi detail adalah tingkat tuntutan terhadap karyawan untuk mampu memperlihatkan ketepatan, analisis, dan perhatian terhadap penugasan secara detail. 
Pengawasan dalam pelaksanaan tugas dikatakan detail jika memiliki tingkat ketelitian dan cepat tanggap dalam pengajuan tuntutan karyawan.

f. Orientasi hasil adalah tingkat tuntutan terhadap manajemen untuk lebih memusatkan perhatian pada hasil, dibandingkan perhatian pada teknik dan proses yang digunakan untuk meraih tuntutan tersebut yang dapat diukur dengan kebebasan cara mencapai tujuan dan mengutamakan hasil kerja.

\section{Motivasi Kerja}

Motivasi terbentuk karena seseorang mulai merasa kebutuhan fisiologis dan psikologisnya tidak dapat dipenuhi sehingga dibutuhkan dorongan untuk memicu tindakan seseorang agar dapat mencapai tujuan atau memenuhi kebutuhannya.

Walaupun motivasi akan menghasilkan suatu perilaku atau tindakan tertentu dari seseorang namun harus dipahami bahwa motivasi berbeda dengan perilaku karena berdasarkan konteks motivasi, perilaku itu sendiri terbentuk karena ingin mencapai tujuan tertentu. Apabila tidak ada tujuan yang ingin dicapai maka motivasi tidak diperlukan sehingga perilaku yang tercermin merupakan kepribadian orang tersebut. Perilaku yang terus berlangsung karena motivasi tertentu akan menghasilkan kinerja dimana kinerja ini sendiri ditetapkan atau merupakan hasil evaluasi dari pihak lain dan bukan penilaian yang dihasilkan oleh orang itu sendiri.

Secara umum, teori motivasi dikelompokkan menjadi tiga kelompok besar, yaitu teori kebutuhan, teori proses, serta teori pembelajaran dan penguatan (Sobirin, 2018, h. 4.39).

a. Teori kebutuhan berasumsi bahwa motivasi bermula dari tidak terpenuhinya kebutuhan sehingga mendorong seseorang untuk berperilaku dan bertindak memenuhi kebutuhan tersebut. Di antara teori kebutuhan, yang banyak mendapat perhatian adalah teori hierarki kebutuhan yang dikembangkan Maslow; ERG theory yang digagas oleh Aldelfer; teori dua faktor (motivator-hyegine theory) yang digagas oleh Herzberg; dan tiga teori kebutuhan (three need theory) yang dibangun McClelland.

b. Teori proses merupakan teori motivasi yang menyoroti proses terjadinya motivasi. Teori ini berasumsi bahwa motivasi tidak hanya disebabkan kebutuhan seseorang, tetapi disebabkan oleh faktor-faktor lain di luar kebutuhan. Artinya, seseorang mau melakukan tindakan bukan karena kebutuhan, tetapi karena pertimbangan-pertimbangan rasional lainnya. Di antara teori proses yang banyak mendapat perhatian adalah teori pengharapan (expectancy theory), teori kesetaraan (equity theory) dan teori penetapan tujuan (goal setting theory).

Menurut Sudirman dalam Purnomo (2018, h. 32), menyebutkan motivasi dapat diartikan sebagai daya upaya yang mendorong seseorang untuk melakukan sesuatu. Motif dapat diartikan sebagai daya penggerak yang dimiliki seseorang dalam melakukan kegiatan atau aktivitas tertentu untuk mencapai suatu tujuan, sehingga motivasi dapat diartikan sebagai daya penggerak yang telah menjadi aktif dilakukan terutama apabila kebutuhan untuk mencapai tujuan sangat dirasakan atau mendesak. 
Faktor-faktor yang memengaruhi motivasi kerja menurut Sudirman dalam Purnomo (2018, h. 33) dipengaruhi oleh faktor-faktor sebagai berikut:

a. Faktor internal adalah faktor yang berasal dari proses psikologis dalam diri seseorang yang terdiri dari kematangan pribadi, tingkat pendidikan, keinginan atau harapan pribadi, kebutuhan, kelelahan atau kebosanan, serta kepuasan kerja.

b. Faktor eksternal atau environment factor adalah faktor yang berasal dari luar diri yang terdiri dari kondisi lingkungan kerja, kompensasi yang memadai, supervise yang baik, terdapat jaminan karier, status dan tanggung jawab dan peraturan yang fleksibel. Menurut Siagian (2008) indikator motivasi terdiri dari:

a. Daya pendorong, yaitu semacam naluri yang dimiliki oleh seseorang tetapi hanya terbatas kepada suatu dorongan kekuatan yang luas terhadap suatu arah yang umum dihadapi seseorang dalam lingkup lingkungan pekerjaannya.

b. Kemauan, yaitu dorongan untuk melakukan sesuatu karena mendapatkan stimulant atau pengaruh dari luar diri seseorang.

c. Kerelaan, yaitu suatu bentuk persetujuan atas adanya permintaan yang berasal dari orang lain agar seseorang dapat mengabulkan atau menyetujui suatu permintaan tertentu tanpa merasa terpaksa dalam melakukan permintaan tersebut.

d. Membentuk keahlian, yaitu proses penciptaan atau pengubahan keterampilan dan keahlian seseorang dalam suatu ilmu dan bidang tertentu.

e. Membentuk keterampilan, yaitu kemampuan melakukan perilaku dan tindakan yang kompleks dan tersusun rapi secara tepat sesuai dengan situasi dan keadaan tertentu untuk mencapai hasil yang diharapkan.

f. Tanggung jawab merupakan kewajiban untuk melakukan sesuatu atau berperilaku menurut cara tertentu.

g. Kewajiban merupakan sesuatu tindakan atau perbuatan yang harus dilakukan oleh seseorang.

h. Tujuan merupakan pernyataan tentang keadaan yang diinginkan dalam organisasi atau perusahaan dimana seluruh unsur dalam organisasi atau perusahaan tersebut berusaha semaksimal mungkin untuk dapat mewujudkannya.

\section{Kinerja Karyawan}

Kinerja merupakan pencapaian atau hasil kerja dari seorang karyawan baik secara kualitas maupun kuantitas yang diperolehnya dalam melaksanakan tugas atau tanggung jawab yang diberikan kepadanya. Kinerja seorang karyawan erat kaitannya dengan kinerja organisasi itu sendiri dimana karyawan sebagai landasan dasar yang menggerakkan organisasi tersebut mampu mencapai tujuan organisasi yang telah ditetapkan apabila kinerja dari karyawan itu sendiri bagus.

Ada banyak faktor yang memengaruhi kinerja dari seorang karyawan menurut Mangkuprawira dan Hubeis (2007) dalam Artadi (2015, h. 11), yaitu:

1. Faktor intrinsik 
Faktor personal atau individual, yaitu pengetahuan, keterampilan (skill), kemampuan, kepercayaan diri, motivasi dan komitmen yang dimiliki oleh tiap individu karyawan.

2. Faktor ekstrinsik

a. Faktor kepemimpinan, meliputi aspek mutu manajer dan team leader dalam memberikan dorongan, semangat, arahan dan dukungan kerja pada karyawan.

b. Faktor tim, meliputi aspek dukungan dan semangat yang diberikan oleh rekan dalam satu tim, kepercayaan terhadap sesama anggota tim, kekompakan dan keeratan anggota tim.

c. Faktor sistem, meliputi sistem kerja, fasilitas kerja atau infrastruktur yang diberikan oleh proses organisasi dan kultur kerja dalam organisasi.

d. Faktor situasional, meliputi tekanan dan perubahan lingkungan internal dan eksternal.

Dalam mengevaluasi kinerja dari para karyawan, suatu perusahaan perlu melakukan penilaian kinerja. Pada umumnya penilaian kinerja dilakukan setiap tahun sekali oleh perusahaan. Penilaian kinerja individu sangat bermanfaat bagi dinamika pertumbuhan organisasi secara keseluruhan, melalui penilaian tersebut maka dapat diketahui kondisi sebenarnya tentang bagaimana kinerja karyawan.

Penilaian kinerja mempunyai lima fungsi utama. Pertama, penilaian kinerja berfungsi sebagai dasar untuk memberi imbalan dan memberi pengakuan terhadap kinerja karyawan. Kedua, penilaian kinerja bisa dijadikan pedoman untuk merekrut, mem-PHK, atau mempromosikan karyawan. Ketiga, penilaian kinerja bisa memberi informasi bagi karyawan untuk mengetahui pengembangan dirinya. Keempat, penilaian kinerja bisa digunakan untuk mengetahui kebutuhan pelatihan yang diperlukan seorang karyawan. Terakhir, kelima penilaian kinerja bisa digunakan untuk mengintegrasikan fungsi perencanaan, manajemen SDM dan koordinasi fungsi SDM lainnya (Sobirin, 2018, h. 4.49-4.50)

Menurut Shaju (2017), mengevaluasi kinerja seorang karyawan dalam suatu organisasi tidak hanya fokus terhadap seberapa puas karyawan dengan pekerjaannya, tetapi juga dengan banyak faktor lain seperti independensi profesional, komitmen organisasi, kecerdasan emosional, sifat disiplin, gaya kerja kolaboratif, perilaku organisasi, dll. Kepuasan kerja adalah atribut psikologis dari karyawan sedangkan prestasi kerja adalah cerminan praktis dari kecakapan karyawan terhadap pekerjaannya yang membuat pemimpin perusahaan gembira.

Menurut Sobirin (2018, h. 4.51-4.52), ada beberapa faktor yang menyebabkan terjadinya kritik terhadap penilaian kinerja, yaitu sebagai berikut:

a. Halo Effect

Yang dimaksud dengan halo effect adalah karakteristik seseorang baik positif maupun negatif memengaruhi keseluruhan sikap orang tersebut.

\section{b. Leniency-Strictly Effect}

Sebagian evaluator memberikan penilaian yang terlalu longgar (leniency) sehingga menguntungkan pihak yang dinilai dan sebagian evaluator memberi penilaian yang terlalu ketat (strict) sehingga merugikan pihak yang dinilai. 


\section{c. Central Tendency Effect}

Kebiasaan lain adalah evaluator hanya memberi nilai rata-rata kepada setiap orang, tanpa memedulikan kinerja sesungguhnya dari setiap karyawan.

\section{d. Interrater Reliability}

Dua orang penilai, meski melihat perilaku yang sama dari seorang karyawan, kedua memberi penilaian yang berbeda.

e. Contrast Effect

Evaluasi terhadap kinerja seorang karyawan dipengaruhi oleh hasil kinerja orang yang telah dinilai sebelumnya.

\section{f. Zero-Sum Problem}

Beberapa sistem penilaian kinerja sering kali menghendaki agar terjadi keseimbangan dalam penilaian kinerja karyawan misalnya dengan memberikan sebagian nilai karyawan yang nilainya tinggi kepada karyawan yang nilainya rendah.

\section{g. Numbers Fetish}

Penilaian kinerja karyawan sering kali terjebak pada angka seolah-olah angka tersebut memiliki tingkat akuasi yang tinggi tanp mempertimbangkan konteks.

h. Recency Effect

Penilaian kinerja sering kali hanya mempertimbangkan apa yang terjadi sekarang tanpa melihat kaitannya dengan penilaian kinerja masa lalu.

\section{METODE PENELITIAN}

Metode penelitian ini menggunakan metode penelitian deskriptif, penelitian deskriptif kualitatif digunakan karena dapat menggambarkan objek penelitian berdasarkan fakta-fakta yang tampak atau sebagaimana adanya. Penelitian dideskripsikan menurut apa adanya pada saat penelitian dilakukan dimana subjek penelitian ini adalah PT. X yang ada di Batam, Kepulauan Riau. Objek penelitian ini adalah budaya organisasi dan motivasi kerja terhadap salah satu perusahaan PMA di Batam.

\section{HASIL DAN PEMBAHASAN}

PT. X sebagai perusahaan PMA yang berada di Batam mulai berdiri pada tahun 2003 dimana saat itu kondisi Batam masih belum seramai saat ini sehingga perekrutan dilakukan di Jakarta dengan memasang iklan di koran dan papan pengumuman universitas yang diharapkan karyawannya dapat berasal dari universitas tersebut. Karyawan-karyawan yang berhasil direkrut ini menjadi orang-orang pertama yang bekerja serta membentuk budaya organisasi bersama dengan pemimpin atau direktur utama sesuai asumsi dasar dan landasan filosofis organisasi.

Sebagai perusahaan yang baru berdiri saat itu, maka belum ada budaya dan struktur organisasi di perusahaan sehingga setiap karyawan bersaing untuk membuktikan dirinya lebih unggul dari karyawan lainnya untuk mendapat pengakuan dan kepercayaan dari pemimpin perusahaan. Setiap orang bersedia secara sukarela untuk melakukan pekerjaan double atau multi tasking. Saat itu, semakin besar dan banyak tanggung jawab yang diberikan maka karyawan 
tersebut akan semakin termotivasi karena merasa dipercaya dan dianggap memiliki kemampuan lebih dari yang lainnya. Namun seiring berjalannya waktu, karyawan yang menjadi pendiri dan pembentuk budaya serta struktur organisasi di perusahaan telah resign sehingga budaya persaingan dan senioritas yang dulu terbentuk mulai terjadi perubahan.

Generasi saat ini tidak menganggap persaingan sebagai sebuah motivasi sehingga budaya saling membantu dan melindungi sesama karyawan menjadi hal lumrah belakangan ini, tidak jarang kesalahan ini ditutupi dan diselesaikan sendiri tanpa menyampaikan kepada manajer departemennya. Tidak seperti sebelumnya dimana tiap karyawan ingin memperlihatkan keunggulannya sehingga tidak jarang rekannya melaporkan kesalahan yang diperbuat oleh rekan lainnya langsung kepada direktur utama untuk dapat menjatuhkan rekannya tersebut. Manajemen inti dan direktur utama dengan sengaja membuat kondisi lingkungan kerja di PT. X sedemikian adanya sehingga tidak diperlukan adanya pengawasan langsung karena dalam hal ini direktur utama dan manajemen inti berada di Singapur dan tak dapat mengawasi secara langsung kegiatan kerja yang terjadi. Persaingan yang dibentuk dalam budaya organisasi menjadi bentuk pengawasan tidak langsung yang dilakukan perusahaan kepada karyawannya.

Sayangnya pergantian karyawan membentuk budaya baru yang terbentuk karena tuntutan perubahan kondisi dimana karyawan PT. X sekarang menginginkan pembagian tugas yang lebih adil, malahan bisa terjadi konflik apabila ada karyawan yang merasa job desknya lebih banyak dari karyawan lainnya. Walaupun tetap saja karyawan saat ini dituntut untuk multi tasking dan memiliki tugas tambahan namun tidak sebanyak sebelumnya dan pembagian tugasnya lebih merata. Perubahan budaya organisasi yang terjadi di PT. X bukan hanya berasal dari bergantinya karyawan melainkan juga karena terjadinya perubahan pemimpin.

Menurut Achmad (2018) dimana dengan beralihnya estafet kepemimpinan, itu berarti kendali organisasi, termasuk proses pembentukan dan mempertahankan budaya organisasi, bergeser dari para pendiri ke putra mahkota atau para manajer professional. Meski pergantian kepemimpinan ini mungkin tidak berdampak terhadap perubahan asumsi dasar dan landasan filosofis organisasi, bukan tidak mungkin pimpinan yang baru melakukan interpretasi ulang terhadap asumsi dasar dan filosofi organisasi. Hal ini bisa saja terjadi utamanya jika terjadi perubahan lingkungan eksternal yang memaksa organisasi harus menyesuaikan diri dengan lingkungan tersebut. Jika para penerus atau manajer professional berhasil menginterpretasi ulang filosofi organisasi dan menjadikan organisasi sukses, selanjutnya nilai-nilai baru ini dikomunikasikan kepada seluruh anggota organisasi, di-shared dan dipertahankan untuk menjadi nilai-nilai bersama.

Kepemimpinan yang baru tidak menerapkan aturan yang jelas bahkan tidak menawarkan hal untuk memicu peningkatan kinerja karyawannya. Pengakuan dan imbalan berupa hadiah atau bonus yang pada kepemimpinan sebelumnya menjadi motivasi tersendiri para karyawan, pada kepemimpinan baru tidak lagi diterapkan. Direktur utama yang baru tidak terlalu memedulikan peningkatan kinerja selama proses produksi dan hasil analisis dapat dilaporkan tepat waktu. Situasi demikian membuat beberapa karyawan lama merasa tidak nyaman dan memilih untuk meninggalkan perusahaan, bahkan karyawan yang baru bergabung kemudian merasa kondisi 
perusahaan dan budaya organisasi di PT. X tidak sejalan dengan visi dan misi karyawan itu sendiri juga memilih untuk resign. Tak ayal banyak karyawan yang melakukan job hopping pada PT. X, namun sekali pun hal ini terjadi perusahaan tak melakukan perubahan dan cenderung mempertahankan fenomena job hopping yang terjadi.

Namun, walaupun dengan kondisi demikian masih ada beberapa karyawan yang tetap memilih bertahan. Setiap karyawan yang masih bertahan memiliki motivasi sendiri sehingga dengan kondisi tanpa ada benefit lain yang ditawarkan oleh perusahaan, selain gaji setiap bulannya, karyawan tersebut masih mau loyal terhadap perusahaan. Salah satu hal yang menjadi motivasi karyawan yang masih bertahan adalah karena kondisi lingkungan kerja yang menerapkan sistem kekeluargaan dimana setiap karyawan saling membantu dan saling memotivasi jika ada masalah, baik itu masalah mengenai kerjaan maupun masalah pribadi. Kondisi demikian menjadi zona nyaman tersendiri bagi karyawan yang masih bertahan, terutama bagi karyawan perempuan yang sudah memiliki anak. Tidak ada tantangan yang begitu berarti dalam pekerjaan di PT. X karena setiap hal yang sulit sebagian besar diselesaikan dan didiskusikan bersama. Selain itu, jam masuk dan mudahnya meminta izin yang tidak seperti perusahaan lainnya menjadi kelebihan tersendiri di PT. X. Walaupun terkadang rasa jenuh juga terjadi karena menganut sistem kekeluargaan sehingga tidak ada aturan yang jelas dan ketat. Aturan seringkali berubah sesuai situasi atau kehendak dari management sehingga kadang merugikan beberapa orang karena tidak adanya sosialisasi menyeluruh kepada karyawan karena management berharap karyawan mengerti dengan sendirinya.

Keharusan untuk memenuhi kebutuhan hidup juga menjadi salah satu motivasi bagi karyawan yang masih bertahan di PT. X sekali pun tanpa adanya jenjang karir dan pengembangan diri selama bekerja di PT. X.

Berdasarkan studi kasus di atas, teori motivasi yang relevan dengan keadaan yang terjadi di PT. X adalah ERG Theory. Hal ini didasarkan bahwa karyawan di PT. X tetap bekerja di perusahaan ini karena harus memenuhi kebutuhan dasar hidupnya. ERG theory diajukan oleh Alderfer. Alderfer berpendapat bahwa kebutuhan-kebutuhan bisa datang dalam waktu bersamaan, tanpa harus menunggu terpuaskannya satu kebutuhan tertentu.Ketiga komponen ERG theory, yaitu :

\section{Existence needs}

Existence needs adalah kebutuhan seseorang untuk bisa bertahan hidup-kebutuhan untuk bisa eksis. Oleh karena itu, kebutuhan jenis ini ini meliputi semua faktor fisiologis dan material lainnya yang dibutuhkan manusia untuk bisa bertahan hidup.

\section{Relatedness needs}

Relatedness needs adalah kebutuhan seseorang untuk bisa berhubungan dan berinteraksi dengan orang lain sehingga dirinya bisa diterima dan menjadi bagian dari masyarakat.

3. Growth needs

Growth needs adalah kebutuhan seseorang untuk bisa tumbuh dan berkembang sesuai dengan potensi diri yang dimilikinya. 


\section{KESIMPULAN}

Budaya organisasi dan motivasi kerja yang terjadi di PT. X memberikan gambaran bahwa karyawan dapat merasa nyaman dan menunjukkan kinerja yang baik apabila budaya organisasi sejalan dengan aturan serta motivasi yang ditumbuhkan di lingkungan kerja. Perubahan budaya organisasi dapat terjadi apabila terjadi perubahan kepemimpinan yang dapat memengaruhi motivasi karyawan. Sebagian besar karyawan di PT. X memilih untuk meninggalkan perusahaan karena terjadi perubahan budaya organisasi yang disebabkan bergantinya direktur utama dan tidak adanya benefit yang dapat diperoleh. Kebijakan yang dijalankan oleh direktur yang baru tidak memberikan motivasi bagi banyak karyawan untuk mempertahankan kinerja atau bahkan mempertahankan posisi mereka sebagai karyawan di PT. X.

Karyawan di PT. X yang masih bertahan disebabkan oleh existence needs dan relatedness needs. Suasana kekeluargaan yang timbul sebagai bagian dari pembentukan budaya baru di PT. $\mathrm{X}$ menjadi zona nyaman tersendiri bagi karyawan yang masih bertahan. Namun motivasi ini tidak menjadi hal yang memicu kinerja karyawan agar lebih baik lagi sehingga karyawan cenderung untuk mempertahankan saja kinerja yang ada tanpa adanya motivasi yang kuat untuk melakukan inovasi dan mengembangkan dirinya. Hal ini sejalan dengan prinsip direktur utama yang baru yang hanya menginginkan pekerjaan selesai tepat waktu tanpa perlu ada pengembangan yang berarti karena PT. X juga tidak menawarkan bonus-bonus lainnya untuk memicu motivasi karyawannya.

\section{DAFTAR RUJUKAN}

Aritonang, Lerbin Roberto. (2019). Metode Penelitian Bisnis (Cet. 7). Tangerang Selatan: Universitas Terbuka

Artadi, Febri Furqon. (2015). Pengaruh Kepuasan Kerja dan Beban Kerja Terhadap Kinerja Karyawan Pada PT. Merapi Agung Lestari (Publikasi No. 16338) [Skripsi Sarjana, Universitas Negeri Yogyakarta]. https://eprints.uny.ac.id/16338/

Indonesia. Otoritas Jasa Keuangan (OJK). (2016). Undang-Undang Republik Indonesia Nomor 25 Tahun 2007 tentang Penanaman Modal. https://www.ojk.go.id/sustainablefinance/id/peraturan/undang-undang/Pages/Undang-Undang-No.-25-Tahun-2007-tentangPenanaman-Modal.aspx

Kusumawardani, Laksmi. (2010). Budaya Organisasi dalam Meningkatkan Kinerja Karyawan. BISMA - Jurnal Bisnis dan Manajemen, Vol. 2 No. 2. https://www.researchgate.net/publication/327774595_Budaya_Organisasi_dalam_Meningkatkan _Kinerja_Karyawan

Morissan. (2017). Metode Penelitian Survei (Cet. 5). Jakarta: Kencana 
M, Shaju dan Subhashini D. (2017). A study on the impact of Job Satisfaction on Job Performance of Employees working in Automobile Industry, Punjab, India. Journal of Management Research, ISSN 1941-899X $2017 \quad$ Vol. 9, No. 1. https://www.researchgate.net/publication/313334566_A_study_on_the_impact_of_Job_Satisfacti on_on_Job_Performance_of_Employees_working_in_Automobile_Industry_Punjab_India

Purnomo, Donny Suryo. (2018). Pengaruh Pelatihan dan Motivasi Kerja Terhadap Kinerja Karyawan dengan POS (Perceived Organizational Support) sebagai Variabel Moderator (Studi pada PT. Bank Pembangunan Daerah Jawa Barat dan Banten Tbk) [Tesis Magister, Universitas Terbuka]. Universitas Terbuka Repository. http://repository.ut.ac.id/8916/

Robbins, Stephen P. \& Judge, Timothy A. (2008). Perilaku Organisasi (edisi keduabelas). Jakarta: Salemba Empat.

Sobirin, Achmad. (2018). Perilaku Organisasi (Cet. 4 Ed. 2). Tangerang Selatan : Universitas Terbuka.

Sugiyono. (2011). Metode Penelitian Kuantitatif, Kualitatif dan R\&D. Bandung: Alfabeta

4 Januari 2017. Penanaman $\quad$ Modal
https://id.wikipedia.org/wiki/Penanaman_Modal_Asing 